\title{
Den nye middelklasse er drivkraften i Kina
}

\section{Hugo Gården}

\section{De 100-200 millioner mennesker i den nye mid- delklasse er den økonomiske drivkraft i Kina, men de udgør også et historisk eksperiment i sam-}

fundsudviklingen, og det kan få stor betydning for resten af verden

Alt dét, formand Mao forsøgte at udrydde med millioner af ofre til følge, er drivkraften i det moderne Kina: Middelklassen. Borgerskabet. Alt dét, rødgardisterne hadede og bekæmpede - borgerskab, kapitalisme, privat ejendomsret og individualisme - er kommet til ære og værdighed.

Kineserne er ikke kommunister og socialister, selv om de har sans for at hjælpe hinanden. De er småborgerlige kapitalister om en hals, og det udtrykkes først og fremmest i den nye middelklasse, der omfatter mellem 100 og 200 millioner mennesker afhængig af, hvordan eksperter definerer middelklassen. Men meget groft ligger middelklassens familieindkomst mellem $50.000 \mathrm{og}$ 500.000 kr. om året.
Dét, der har skabt væksten de seneste år, er kæmpestore statslige infrastrukturprojekter samt den statsligt iværksatte industrieksport. Det har resulteret i de støt stigende eksportindtægter, der kan gøre Kina til verdens største økonomi om en snes år - målt i købekraft.

Men det er alligevel middelklassen, der er drivkraften, for det er den, der får det nye Kina til at fungere, og det er den, der er kernen i både erhvervslivet (privatejede virksomheder står bag hovedparten af eksporten) og det stærkt voksende forbrugersamfund, som fremover skal trække en større del af læsset.

Det er uhyre interessant at se middelklassens udvikling, for den optræeder meget anderledes end middelklassen i Vesten - ja, vi har vel 
ikke en decideret middelklasse i dag, eftersom langt de fleste er blevet en slags middelklasse. Men hvis den kinesiske middelklasse vil udvikle sig lidt i retning af den vestlige, bliver det snarere i en amerikansk end i en europæisk retning, da kineserne i ekstrem grad er sig ejerskabets velsignelser bevidste: De vil eje deres bolig, de vil have aktier, de er ikke bange for at etablere egen virksomhed, og de accepterer enorme uligheder.

Mange har svært ved at tro, at den høje økonomiske vækst kan fortsætte, men middelklassen giver én af forklaringerne. Der er en ubegribelig dynamik i kineserne, og især i alle, der har deres egen virksomhed, og de kæmper alle som én for at gøre den endnu større. Mange har den holdning, at først skal de være stærke i deres by eller region. Så skal de have en stærk position i hele Kina. Og så skal de ud på verdensmarkedet. De er langt mere stræbsomme end europæerne, og formentlig også amerikanerne.

Det er først i de seneste ca. fem år, at omverdenen er blevet klar over middelklassen og dens betydning ikke bare i Kina, men i alle de nye $ø$ konomier. For nu ser man middelklassen tydeligt, når store, moderne biler fylder Shanghais gader, når byen er fyldt med unge kvinder på shopping-ture i feminint modetøj, når private virksomheder flytter ind i supermoderne forretningshøjhuse i Beijing, og når forretningsfolk fra den industrielle Guangdong-provins tager på weekendture med fly til ferieøen Hainan eller til Yuannan-provinsen.

Der findes ingen elektronisk dims i Europa, som ikke allerede findes i Kina - den ægte eller kopierede vare - dvs. til en enorm prisdifferentiering, så både rig og fattig kan være med på modebølgen, og så de kan koble sig på det globale samfund.

\section{Middelklassens udvikling}

Middelklassen begyndte at udvikle sig på et tidligere tidspunkt, for 1020 år siden, og det giver en central forståelse for middelklassens styrke og betydning. Indtil midten af 1990'erne var det sjældent, at folk ejede deres bolig eller deres virksomhed, og aktiemarkedet var kun i sin vorden.

Nogle af de meget velhavende kinesere i dag begyndte deres private løbebane for ca. 20 år siden, ikke mindst i ejendomsbranchen, men det var først med en reform af ejendomsmarkedet i 1998, at det for alvor blev muligt for folk at købe deres hus eller lejlighed. Det gav et boom i boligkøbet og -byggeriet, og det viste sig, at kineserne rådede over bugnende pengemængder, som dukkede op fra madrassen, som lån fra slægtninge og fra bankkonti, og kineserne købte ikke bare en bolig til privatbrug, men også en ekstra bolig som investeringsobjekt - eller 
flere. Gamle, dårlige statslige boliger fik pludselig værdi. Grunden var lagt for privatiseringen gennem en halv snes år. Det kom ikke voldsomt som i Rusland.

Nogle år senere udviklede aktiemarkedet sig også kraftigt, men meget ustabilt og med utroværdige informationer, så markedet brød reelt sammen. Med skærpede regler for markedet begyndte det igen i 2005, og det eksploderede med en glubende interesse for at købe aktier. I dag er der flere private aktionærer i Kina end i USA, vel omkring 100 millioner, og midaldrende og ældre kinesere stimler sammen hver dag foran store skærme med kursgrafik og data ved de talrige børsmæglerselskaber, der er skudt op i storbyerne.

Atter engang er mere eller mindre skjulte midler blevet aktiveret og trukket ind i et erhvervsliv, der buldrer afsted. Markedet udviklede sig euforisk. Det er faldet kraftigt de seneste måneder, men de fleste har alligevel fået store kursgevinster, som har givet folk mulighed for at købe endnu en bolig eller en bil - og ofte kontant.

Man ryster på hovedet, når man ser, en familie med en samlet månedsindtægt på højst $7000 \mathrm{kr}$., som har haft råd til at købe en bil til $100.000 \mathrm{kr}$. kontant på grund af kursgevinster, og som sidder i eget hus.

Den relativt lange periode med privatisering af økonomien, først med køb af egen bolig, har gjort ki- neserne selvbevidste om deres nye økonomiske tilværelse. De ignorerer det kommunistiske politiske system, for de har fået mulighed for at skabe deres egen tilværelse med en fri økonomi og med fri råderet over deres indtjening og formue.

Mange husker terroren under Kulturrevolutionen og de fattige vilkår 10-20 år senere, og de vil ganske enkelt være velhavende i en fart. De har en kapitalistisk og materialistisk indstilling, der somme tider siger spar-to til vores. De kæmper for sig selv. Derfor ser man også enorme indkomstforskelle, og det accepterer kineserne åbenbart. Fattige og velhavere lever side om side. Alle er besjælet af, at de har muligheden for at komme frem.

\section{Rigdom skal ses}

Indkomstforskellene er større end i USA, og det er forbavsende at se, hvor mange tusinde velhaverboliger, der konstant skyder op i rigmandskvarterer i fx Shanghai og Beijing. Mange af boligerne sætter Hellerupvillaer i skyggen, med søjler og portaler i en spansk, græsk eller amerikansk snit.

I storbyerne sælges ejerlejligheder i højhuse rask væk for en, to og fire millioner kr. til den nye kinesiske middelklasse, som har en årlig husstandsindkomst på mellem 50.000 og $500.000 \mathrm{kr}$. En mellemleder i en udenlandsk virksomhed kan tjene 150.000 kr. om året. Til sammenlig- 
ning er lønnen for industriarbejderen på under $10.000 \mathrm{kr}$. om året, så industriarbejderne hører altså ikke til i middelklassen, med mindre de har været heldige med aktier og ejendomme, hvad utroligt mange har. Selv rengøringskoner er aktionærer.

I den nye middelklasse er det vigtigt med show-off. Ens rigdom eller indkomst skal ses. Det mærker en virksomhed som den danske smykkeforretning Dyhrberg/Kern. Unge kvinder kan spare sammen i lang tid for at købe et smykke, der koster opsparingen fra en månedsløn, for smykket er en personlig markedsføring af den pågældende.

Huse skal se dyre ud og absolut ikke ligne danske étplanshuse i parcelhuskvartererne. Et af højdepunkterne i velstands-promoveringen er bryllupperne, der er rent business. Et brudepar og forældrene går til et bryllupsfirma, som ordner alt omkring fotografering (der kan vare en hel dag i naturskønne omgivelser) til arrangering af bryllupsdagen med op til flere receptioner og hundreder af gæster, og hvor udgiften for middelklassen let løber op i $100.000 \mathrm{kr}$. Altså en årsløn, som betales på forældre-siden. Dertil kommer, at pigen normalt forventer, at manden har en ejerbolig og bil.

Det show-off, som et bryllup også er, fører ofte til økonomisk ruin for brudgommens forældre, men selv om den slags overdådighed og selvpromovering understreger vel- standsræeset, så understreger det også en vis sammenhængskraft i det nye kinesiske samfund. Familien har stadig en stor rolle at spille i valget af ægtefælle, og når ægteskabet er indgået, bliver man sammen, for dels er der investeret heftigt i brylluppet, dels er det vanærende for familie, venner og forretningsforbindelser, hvis det stort anlagte ægteskab falder på gulvet.

\section{Kinesiske forbindelser}

Individualismen stortrives i middelstanden, men livsnerven i den er stadig de klassiske kinesiske forbindelser, der knytter enkeltaktørerne sammen. Det er meget svært for individerne at bryde ud af disse bånd, men det er også forbindelser, som gør det muligt for enkeltpersonerne at skaffe sig investorer og politisk opbakning, så de kan banke millionforretninger og siden hen milliardforretninger op på ti år.

Den grundliggende individualitet, som findes i Vesten, findes ikke i samme omfang i Kina. Den er knyttet ubrydeligt til familien og nogle interessegrupper, og det er også med til at forklare, hvorfor virksomheder kan udvikle sig så kraftigt. Det er let at finde samarbejdspartnere, der hjælper hinanden fremad, men det indebærer også, at de pågældende er smedet sammen i et ubrydeligt samarbejde.

At skabe forbindelser er også årsagen til, at mange private virksom- 
hedsejere går ind i kommunistpartiet. Det er absolut ikke, fordi de er blevet kommunister, men de erkender, at de må pleje forbindelser til magthaverne. De ønsker at påvirke magthaverne indefra, fx om den lovgivning, der rammer virksomhederne, fx skattelovgivningen, og endelig ser de værdien i at have en stærk central instans, der kan lave en rammelovgivning, som er holdbar gennem både fem og ti år, og som giver erhvervslivet mulighed for at fortsætte med fuld kraft.

Fra Kina og fra denne gryende styringsmodel er der virkelig noget at lære for de europæiske samfund, der er gået i stå, økonomisk og udviklingsmæssigt.

\section{Plads til det hele}

Et af de nye partimedlemmer, Chen Ailian, kom kørende i sin Rolls Royce til partikongressen i år og måtte selvfølgelig forklare sig. Det gjorde hun uden besvær. Der skal være plads til det hele, mener hun. Hun begyndte som lastbilchauffør og er nu direktør for en af de største kinesiske private virksomheder, Wanfeng, som er Asiens største producent af aluminiumfælge. Hovedparten af de 12 millioner private firmaer har partiforeninger i deres virksomhed. Partiet og de private virksomheder kobles mere og mere sammen, men den kapitalistiske ånd i erhvervslivet er ikke på nogen måde blevet mindre.
Tværtimod slår middelklassens interesser igennem på en overraskende måde. Når titusinder af borgere organiserer en protestbevægelse via deres mobiltelefoner eller blogs mod en forurenende fabrik eller mod linjeføringen af magnetjernbanetoget i Shanghai, så har det virkning. Det har større virkning, end når tusinder af landmænd protesterer mod konfiskation af deres jord i fjerntliggende egne af landet.

Når tusinder eller millioner af mennesker via internettet kritiserer den elendige byggestandard, som har været medvirkende til, at mindst 50.000 mennesker døde under jordskælvet i Sichuan, så får det betydning: De genopbyggede huse og især skoler og hospitaler skal være jordskælvssikre.

Der har også været en omfattende kritik - på nettet - af, at rige kinesere og private koncerner har ydet forsvindende lidt i donationer til de jordskælvsramte i forhold til deres enorme indtjening. Kun USA har flere dollar-milliardærer end Kina. Kineserne lader sig ikke længere kue.

Dét der forbavser alle besøgende i Kina, er dynamikken i planlægningsarbejdet og infrastrukturen. Når der skal bygges nye boligområder og industriparker for tusinder af mennesker, så bliver nye veje rullet ud på forhånd, og hele infrastrukturen kommer på plads, så alt fungerer fra dag nr. ét.

En ny millionby kan etableres på tre år. Sådan noget er utænkeligt i 
Vesten, men det er dagligdagen i Kina, og det giver middelklassen nogle konkurrencefordele, som overgår alt i denne verden. Der åbner sig hele tiden gigantiske markedsmuligheder.

I Shanghai er der forventning om, at fem millioner borgere flytter til nyetablerede byer i omegnen inden for de kommende ti år. Samtidig flytter endnu flere til byområderne, især de tre regioner omkring Beijing, Shanghai og Guangzhou.

Mindst 100 millioner mennesker fra landet ventes at flytte til byerne. Generelt ventes befolkningstallet i byerne at stige fra 42 pct. af befolkningen i 2005 til 81 pct. i 2050.

\section{By kontra land}

Hos middelklassen i byerne ser man en ny holdning: De ser ned på landbefolkningen, selv om der er 130 millioner landarbejdere, der som andre fremmedarbejdere bor i byområderne og sikrer byggeri i et lynende tempo og produktion af industrivarer til udlandet.

Undersøgelser og snak mand-ogmand imellem viser, at byens middelklasse ikke ønsker at dele alt med de 700-900 millioner mennesker i landdistrikterne. Byfolk tjener tre gange så meget som folk på landet. De har en høj vækst i forbruget - på over 20 pct. om året - og har bedre jobmuligheder og uddannelsesmulighederne for børnene, og det vil de ikke sætte over styr ved at dele det med landbefolkningen. Men på længere sigt er dette skisma dog det største spændingsmoment i Kina.

Da der heller ikke er nogen trang til at beskæftige sig med politik i den unge generation - 300 millioner er under 30 år, og tallet vil vokse til 500 millioner inden 2015 - så er dagligdagen for de unge helt igennem materialistisk og ego-centreret, men til gengæld begynder de i stigende grad at kæmpe for at forbedre deres egne, snævre rettigheder.

De ser en interesse i, at den nuværende økonomiske model, hvor det kommunistiske Kina ledes som et holding- eller aktieselskab, bevares. De ser fordele i den hurtige ekspansion af økonomien og infrastrukturen og i den gennemgående frihed til at leve privat, som man vil, vel at mærke under hensyntagen til de generelle normer i familien, på arbejdspladsen og i samfundet. Omvendt erkender kommunistpartiet, at det har brug for andre typer eksperter i ledelsen, fx forskere og virksomhedsfolk.

At middelklassen har fået rettigheder, som landbefolkningen ikke har fået, ses med vedtagelsen af loven om privat ejendomsret. Borgerne kan eje deres egen virksomhed, og de kan eje deres bolig og kan sælge den. Men bønderne har ikke fået ejendomsret til jorden. I det lange løb bliver det utvivlsomt nødvendigt at give ejendomsret til bønderne, så de dels kan sælge jorden, dels købe op for at danne store landbrugsen- 
heder, der kan sikre en voksende fødevareproduktion med færre ressourcer. Meget tyder på, at det er dette sidste aspekt, der vil få partiet til at give bønderne ejendomsret.

Ejendomsretten i byerne, som selvsagt også omfatter bilen og aktierne, har givet den nye middelklasse en helt ny mentalitet og identitet. Middelklassen er bevidst om dens eget værd som drivkraften i samfundet, og når virksomhedsejere går ind i partiet er det formentlig første skridt til, at alle i middelklassen bliver mere engageret i politik, i første omgang for at forsvare deres specifikke rettigheder, fx gennem grundejerforeninger.

Men et politisk systemskifte er der ikke udsigt til i en meget lang årrække. Når den voksende kløft i indkomsten mellem land og by ikke ser ud til at skabe et problem foreløbig, så skyldes det også, at der trods alt er en procentuel stor fremgang på landet, til tider større end i byerne.

Selvbevidstheden er så stor, at der kan opstå en nationalistisk stemning. Det blev tydeligt set omkring Tibeturoen og de udenlandske forsøg på at boykotte OL. Regeringen kan ganske vidst let skabe stemninger i befolkningen, men reaktionerne fra borgerne kom så hurtigt og voldsomt, igen via sms og blogs, at der tydeligvis var tale om en folkelig harme, som selv regeringen blev bekymret for. Den ønsker ikke en konfrontation med omverdenen inden OL.

At skabe økonomisk udvikling, dvs. at komme ud af fattigdommens svøbe, går forud for alt andet for den nye generation, og derfor spiller politiske, religiøse og etniske hensyn en underordnet rolle, og OL skal som et reklameskilt vise den øvrige verden: Se, hvad Kina har opnået på bare 30 år.

\section{Frygtløse investorer}

Middelklassen i byerne udgør et samfund i sig selv, men som tidligere nævnt alligevel knyttet til kommunistpartiet - eller snarere til en statslig, kejseragtig topledelse. Det er i allerhøjeste grad middelklassen, som er investorerne i de selskaber, som flokkes på børsen.

Sidste år blev Kina det land i verden, der hentede flest penge på børsen, dvs. mere end i USA. Markedsværdien i Shanghai var sidste år på over 350 milliarder kr. 57 pct. af investorerne var private aktionærer mod 20 pct. i New York. 70 pct. kom fra de tre toneangivende byer.

De fleste af aktionærerne har haft aktier i mere end fem år. De kan med rette føle, at de er med til at bringe de kinesiske selskaber ud på verdensmarkedet i en tid, hvor amerikanske finansselskaber leder efter kapital - og henter den i Kina. De voldsomme tab i USA får massiv omtale i kinesiske medier.

Investorerne hører til i den bedre end af middelklassen. To tredjedele har fast ejendom. Men det pudsige er, at de ikke er særligt vidende om 
finansforhold. Utroligt mange investerer på grundlag af lykketal og de rygter, der altid svirrer. Tre fjerdedele kender intet til de fundamentale begreber i et regnskab og omkring kursværdier. Den kinesiske spillernatur fornægter sig ikke, men den giver sig altså også udslag i en gudsbenådet frygtløshed, der får de sovende penge til at yngle i erhvervslivet $\mathrm{i}$ et omfang, der er utænkeligt i fx Danmark.

\section{Ingen kinesisk jantelov}

Drivkraften i middelklassen skyldes i høj grad, at alle kan se, at talrige mennesker kan skabe sig formuer på 10 og 20 år og på de mest bemærkelsesværdige måder. Det skaber ikke misundelse. Janteloven er ikke oversat til kinesisk. Her håber alle at kunne finde guldet.

En engelsklærer, den 44-årige Michael Yu, etablerede i 1993 en sprogskole, New Oriental, sammen med sin kone. Den er i dag den førende med 800.000 studerende, og i 2006 blev firmaet børsnoteret i New York, hvor firmaet hentede over 600 millioner $\mathrm{kr}$.

Den i dag 50-årige 'papdronning', Zhang Yin, har på 12 år skabt sig en personlig formue på 20 milliarder $\mathrm{kr}$. ved at lave pap af genbrugspapir, som hun importerer fra USA.

Yin Mingshan, der i dag er en ældre herre på 70 år, etablerede i 1992 en motorcykel- og bilfabrik for $150.000 \mathrm{kr}$. Den er i dag en af lan- dets største private virksomheder med eksport, med 9000 ansatte og med en personlig formue på godt 800 millioner kr.

Næste generation af rige er på vej, og den rigeste er den 26-årige kvinde Yang Huiyan, der har arvet sin formue, 80 milliarder kr., efter faderen, Yang Guoqiang, der fra ingenting har skabt Kinas største byggeudviklingsfirma, Country Garden.

De velstående er blevet forbilledet for den nye middelklasse. Derfor er der også kamp om at få en lederuddannelse, der betragtes som indgangsbilletten til en rig tilværelse. De såkaldte business-schools stortrives, og der spyttes så mange akademikere ud, at der er kamp om pladserne i erhvervslivet. Skolesystemet avler således en konkurrencementalitet, og mange tager chancen som virksomhedsejere, når de ikke kan få godt betalte job.

Det hele begyndte for kun 30 år siden, hvor Kina var fattigere end Indien. I dag er Kina blevet verdens næstrigeste land målt på købekraft, siger Verdensbanken.

Kina løber fra alle andre. Men ikke fra de danske minkavlere. De har forstået at komme ind på livet af de nyrige kinesiske forbrugere med en unik markedsføring af skind. Med et omfattende uddannelsesprogram for designere og personalet $\mathrm{i}$ pelsbutikkerne hjælper minkavlerne og auktionshuset Kopenhagen Fur den kinesiske pelsbranche med at blive verdens førende. 
Det eventyragtige eksempel viser, at det er muligt for kreative erhvervsfolk i det stagnerende Vesten at koble sig på den mest dynamiske udvikling i verdens nye middelklasse. Alle unge kinesere kender H.C. Andersen, og den lille, sarte nattergal kan stadig opløfte sin røst i kæmperiget.

Når den danske designer Carsten Jørgensen, manden bag Bodum-kaffekanden, fra sin nye tegnestue i Shanghai har tegnet en nattergalstatuette i keramik for årets danske erhvervsmand i Kina, så er det helt bevidst: Der er plads til den lille og den store, og selv det store rige kan være skrøbeligt som det tyndeste keramik.
Holder Kina med denne spænding eller dette samspil mellem middelklassen og étpartistaten? Ingen ved det. Men vi er vidne til et enestående historisk eksperiment, som i alt for ringe grad er blevet analyseret, vel fordi det bryder med alle forestillinger om, hvordan et samfund kan eller bør udvikle sig.

Men eksperimentet kan være dét, der får størst virkning for flertallet af menneskeheden i den nye, ikkevestlige verden.

Hugo Gården, journalist, Dagbladet Børsens korrespondent $i$ Shanghai. 